\title{
Kondiloma Akuminata Pada Wanita Hamil: Salah Satu Modalitas Terapi
}

\author{
Satya Wydya Yenny, Rahmah Hidayah
}

\section{Abstrak}

Latar belakang: Penatalaksanaan kondiloma akuminata memerlukan pertimbangan terhadap jumlah, luas, lokasi dan kondisi pasien. Pada wanita hamil, penatalaksanaan kondiloma akuminata harus mempertimbangkan keamanan pada ibu dan janin. Salah satu modalitas terapi yang aman untuk wanita hamil berdasarkan Centers for Disease Control and Prevention (CDC) 2010 adalah asam trikloroasetat (TCA) 80\% - 90\%, tetapi ada beberapa laporan kasus yang menyatakan keberhasilan terapi dengan TCA 50\%.

Kasus: Seorang wanita usia 25 tahun, hamil trimester kedua, mengeluhkan adanya benjolan seperti kutil di daerah kemaluan sejak dua bulan yang lalu dan makin lama makin bertambah banyak. Riwayat kontak seksual dengan pria selain suami disangkal dan suami pasien juga mengeluhkan adanya kutil di kemaluan sejak empat bulan yang lalu. Lesi berupa papul multipel dengan permukaan verukosa. Hasil pemeriksaan acetowhite positif. Pasien diterapi dengan TCA $50 \%$ dengan hasil yang memuaskan.

Kata kunci: kondiloma akuminata, wanita hamil, TCA 50\%

\begin{abstract}
Background: Management of condyloma acuminata requires a consideration of the number, size, location, and condition of the patient. In a pregnant woman, the treatment of genital warts should consider the safety of the mother and fetus. One of therapeutic modalities which is safe for pregnant women based on Centers for Disease Control and Prevention (CDC) is $80 \%$ - 90\% trichloroacetic acid (TCA), but there are some case reports mentioned about successful of therapy with 50\% TCA.Case: A 25-year-old pregnant woman has complained about little lumps like warts in her genitals since two months ago and they are increasing in more numbers.. A history of sexual contact with other men except her husband was denied and her husband has also complained about genital warts since four months ago. Lesions are the multiple papules with verucose surface and the result of acetowhite procedure was positive. This patient was treated by TCA $50 \%$ with good result.
\end{abstract} Keywords:condyloma acuminata, pregnant woman, TCA 50\%

Affiliasi penulis : RSUP DR M. Djamil / Fakultas Kedokteran Universitas Andalas, Padang

Korespondensi :Satya Widya Yenny. RSUP DR M. Djamil / Fakultas Kedokteran Universitas Andalas, Padang

\section{Pendahuluan}

Kutil anogenital yang sering disebut kondiloma akuminata adalah penyakit menular seksual yang disebabkan oleh Human Papilomavirus (HPV). ${ }^{1,2}$ Infeksi HPV dapat menyebar melalui kontak langsung atau autoinokulasi. Masa inkubasi bervariasi dari 1-12 bulan dengan rata-rata $2-3$ bulan. $^{3}$ Infeksi HPV pada genital diduga subklinis sampai $70 \%$, dan tidak disadari oleh pasien tetapi terdeteksi dengan pemeriksaan klinis lengkap, histologis, dan sitologis atau analisis molekular.

Kondiloma akuminata memiliki infektivitas yang tinggi, di mana permukaan mukosa yang lebih tipis akan lebih rentan terhadap inokulasi virus dibanding kulit yang memiliki keratin tebal. Infektivitas HPV genital dari ibu sehubungan dengan papiloma pada anak tampaknya rendah, namun risiko penularan dari ibu ke anak dengan perkembangan penyakit selanjutnya pada anak diperkirakan 1 antara 80 dan 1 antara $1500 .^{4}$

Selama kehamilan, kondiloma akuminata dapat berproliferasi dengan cepat karena perubahan imunitas dan peningkatan suplai darah, dan kelainan ini dapat muncul dalam bentuk klinis atau subklinis (laten). Bentuk klinis lebih menyebabkan gangguan emosional dan fisik pada pasien karena ibu harus melahirkan secara sectio caesaria dan jika melahirkan secara spontan akan terdapat kemungkinan risiko kontaminasi HPV pada bayi. ${ }^{4}$

Modalitas terapi utama untuk kondiloma akuminata adalah terapi destruktif, seperti kauterisasi, krioterapi dengan nitrogen cair, eksisi, tingtura podofilin, podofilin resin, asam trikloroasetat (TCA), injeksi bleomisin sulfat, krim imiquimod dan laser vaporisasi, tetapi tidak ada dari modalitas terapi ini yang memberikan jaminan kesembuhan dan rekurensi biasa terjadi. ${ }^{4}$ Pada wanita hamil tidak semua modalitas terapi di atas dapat digunakan, pilihan terapi yang dapat diberikan antara lain krioterapi, elektrokauterisasi, terapi laser, dan asam trikloroasetat. ${ }^{5}$ Dari keempat modalitas terapi di atas, TCA tidak membutuhkan peralatan khusus karena dapat diaplikasikan langsung di atas lesi, sehingga mudah digunakan dan biaya lebih murah. Berdasarkan Centers for Disease Control and Prevention (CDC) 2010, konsentrasi TCA yang digunakan untuk terapi kondiloma adalah $80 \%$ - 90\%, tetapi ada beberapa laporan kasus yang menyatakan keberhasilan terapi dengan TCA $50 \%$. 


\section{Laporan kasus}

Pasien wanita 24 tahun, sudah menikah dan sedang hamil empat bulan mengeluh terdapat kutil pada alat kelaminnya sejak dua bulan lalu. Keluhan ini tidak pernah dialami wanita muda ini sebelumnya. Awalnya kutil muncul hanya sedikit pada bibir kemaluan bagian luar kemudian makin bertambah banyak hingga ke dinding vagina bagian luar. Kutil tidak gatal dan tidak nyeri serta tidak pernah berdarah.

Pasien baru menikah selama lima bulan dan menyangkal riwayat kontak seksual dengan pria lain kecuali suami. Ini merupakan pernikahan pertama bagi pasien dan suaminya. Setiap melakukan hubungan seksual, suami pasien tidak menggunakan kondom dan hubungan seksual dilakukan secara genitogenital. Pasien tidak pernah memiliki riwayat penyakit lain di alat kelamin dengan gejala seperti tukak atau lecet dan keputihan. la juga tidak mengalami penurunan berat badan dalam enam bulan terakhir, tidak menderita penyakit internal lainnya, dan tidak dalam pengobatan steroid untuk jangka waktu lama.

Suami pasien juga mengeluhkan adanya kutil pada penis sejak empat bulan yang lalu dan mengaku melakukan hubungan seksual dengan wanita lain. Keluhan kutil kelamin ini merupakan pertama kalinya dialami oleh suami pasien dan tidak ada riwayat pengobatan kutil sebelumnya.

Pada pemeriksaan fisik didapatkan papul multipel, soliter dan beberapa papul konfluens dengan permukaan verukosa pada labia mayora, labia minora, dan dinding vagina luar. Pemeriksaan acetowhite pada lesi dan perilesi menunjukkan hasil positif.

Pilihan terapi yang diberikan pada pasien adalah TCA $50 \%$ secara bertahap tiap minggu. Setelah 6 kali terapi, diperoleh hasil yang memuaskan dimana $90 \%$ lesi kutil/kondiloma sudah terangkat serta tidak ditemukan adanya efek samping pada pasien dan janinnya. Suami pasien diterapi dengan bedah listrik. Pasangan ini disarankan untuk tidak melakukan hubungan seksual sampai dinyatakan sembuh atau menggunakan kondom jika ingin melakukan hubungan seksual. Pasien kemudian dianjurkan untuk pemeriksaan DNA HPV dan dikonsultasikan ke Bagian Obstetri dan Ginekologi untuk kemungkinan adanya lesi kondiloma akuminata di daerah serviks serta memeriksa keadaan janinnya. Berdasarkan hasil konsul ke Bagian Obstetri dan Ginekologi, tidak ada kelainan pada janin.

\section{Sebelum terapi}

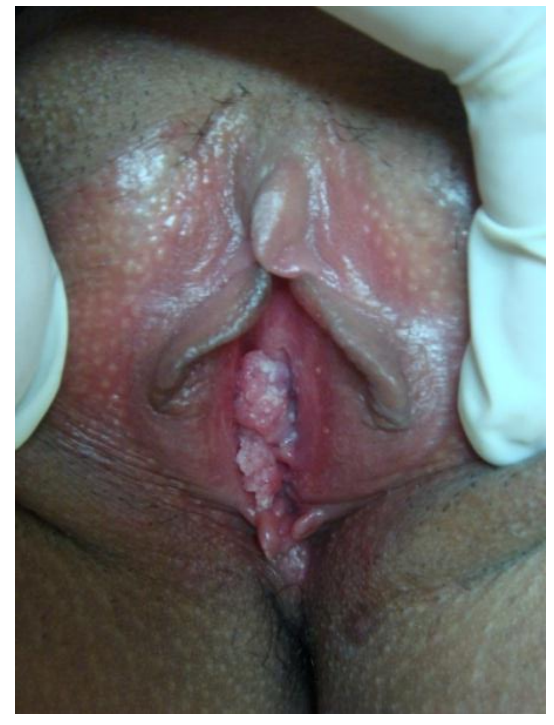

\section{Saat pengolesan TCA $50 \%$}

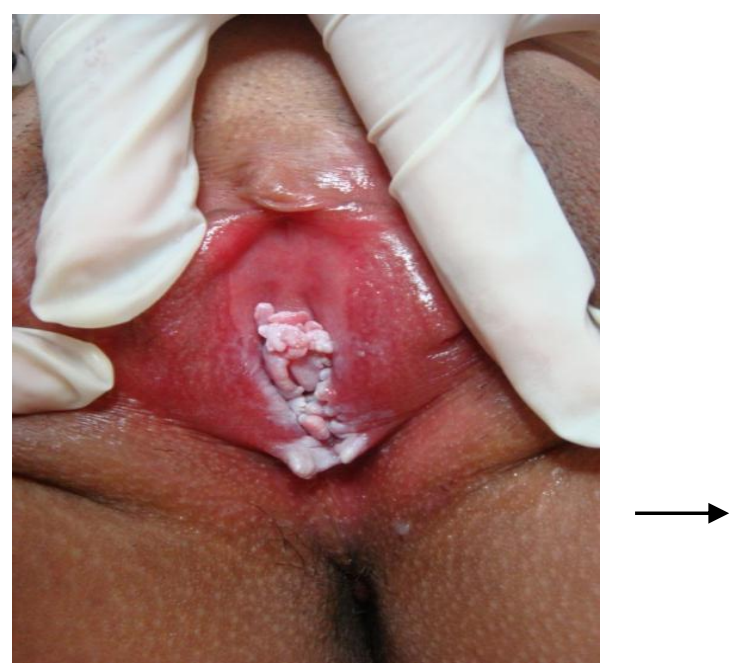

\section{Setelah terapi}




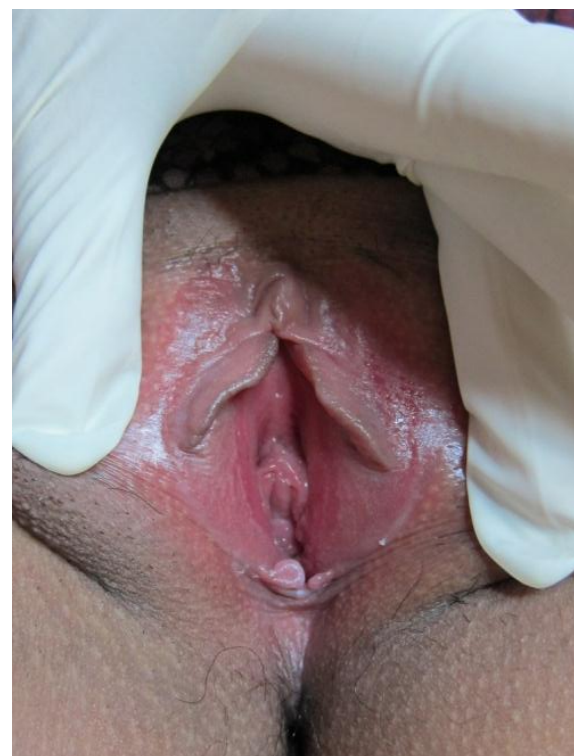

\section{Diskusi}

Kondiloma akuminata hampir selalu ditularkan melalui kontak seksual, tetapi juga dapat terjadi transmisi vertikal dari ibu ke bayi dan autoinokulasi, walaupun jarang terjadi. Masa inkubasi HPV bervariasi dari 3 minggu sampai 8 bulan, dengan rata-rata 2-3 bulan setelah awal kontak. ${ }^{8}$ Pada kasus ini, diduga sumber penularan berasal dari suami pasien yang sudah menderita kutil pada daerah penisnya sejak 2 bulan sebelumnya.

Prevalensi infeksi HPV dalam bentuk kondiloma akuminata sekitar $1 \%$ pada orang dewasa aktif secara seksual. Sekitar $15 \%$ dari kelompok yang terinfeksi mengalami infeksi subklinis atau laten dan setidaknya $80 \%$ sudah terinfeksi dengan satu atau lebih jenis HPV genital. Tingkat tertinggi frekuensi infeksi terjadi pada kelompok dewasa usia 18 - 28 tahun. Selama 20 tahun terakhir prevalensi penyakit ini menunjukkan angka pertumbuhan yang konstan termasuk pada wanita hamil. ${ }^{9}$

Kondiloma akuminata dapat berkembang selama kehamilan karena perubahan imunitas dan peningkatan suplai darah. ${ }^{4}$ Transmisi HPV dari ibu ke bayi jarang terjadi, namun dapat menyebabkan terjadinya respiratory papillomatosis yang dapat mengakibatkan kematian atau morbiditas seumur hidup pada anak. ${ }^{9}$ Selain itu, infeksi HPV pada trofoblas ekstravili dapat menginduksi kematian sel dan mengurangi invasi plasenta ke dinding rahim sehingga menyebabkan disfungsi plasenta dan secara spontan dapat menyebabkan kelahiran prematur. ${ }^{4}$

Meskipun pengobatan kondiloma akuminata dalam kehamilan dibenarkan untuk indikasi baik maternal maupun janin, sebagian besar jenis pengobatan tidak dapat dengan aman digunakan. Podofilin kontraindikasi digunakan karena absorbsi sistemik dapat terjadi, yang dapat menimbulkan malformasi, kelahiran prematur dan kematian janin intrauterin. ${ }^{10}$ Imunoterapi seperti imiquimod krim 5\% tidak menimbulkan efek teratogenik pada hewan coba, tetapi masih membutuhkan data yang lebih banyak tentang keamanannya untuk digunakan pada wanita hamil.
Krioterapi, elektrokauterisasi, terapi laser, dan asam trikloroasetat adalah pilian terapi kondiloma akuminata yang dapat digunakan untuk wanita hamil. Namun, laser $\mathrm{CO}_{2}$ dan elektrokauterisasi dapat menyebabkan perdarahan yang berat pada 33\% pasien bila dilakukan pada kehamilan, serta dapat menimbulkan infeksi dan nekrosis jaringan yang berat. Sedangkan laser Nd YAG yang menembus lebih dalam dapat memberikan hasil yang lebih baik tetapi sangat mahal dan tidak tersedia di setiap rumah sakit. $^{10}$

Asam trikloroasetat (TCA) merupakan zat yang bersifat kaustik dan dapat mengikis kulit dan membrana mukosa. Mekanisme kerja TCA adalah dengan cara koagulasi protein yang menyebabkan terjadi kekeringan sel dan jaringan sehingga dapat mengakibatkan terjadinya destruksi yang berat pada kondiloma. Asam trikloroasetat dinyatakan aman digunakan pada kehamilan karena tidak diabsorbsi secara sistemik. Zat ini dapat diaplikasikan langsung ke permukaan lesi dengan lidi/kapas lidi aplikator setiap minggu. Tingkat keberhasilan TCA untuk terapi kondiloma adalah $56-81 \%$ dengan tingkat rekurensi $36 \%{ }^{11-13}$ Pada pasien ini dipilih TCA $50 \%$ sebagai terapi dengan mempertimbangkan tingkat keamanan dibanding alternatif terapi yang lain, ketersediaan modalitas terapi dan biaya yang lebih murah. Setelah enam kali aplikasi didapatkan hasil yang memuaskan dan tidak ada efek samping pada pasien dan janin.

\section{Daftar Pustaka}

1. Kautsky LA, Kiavit NB. Genital human papillomavirus infection. In: Holmes KK, Sparling F, Stamm WE, Piot P, Wasserheit JN, Corey L, et al, editors. Sexually transmitted diseases. $4^{\text {th }}$ ed. New York: McGraw-Hill; 2008 :489-508.

2. Kilkenny $M$, Marks $R$. The descriptive epidemiology of warts in the community. Aust $\mathrm{J}$ Dermatol, 1996; 37: 80-6.

3. Pfister H, Fuchs PG, Majewski S, Jablonska S, Pniewska I, Maleiczyk M. High prevalence of epidermodysplasia verruciformis associated HPVDNA in actinic keratosis of immunocompetent population. Arch Dermatol Res, 2003; 295: 273-9.

4. Eassa $\mathrm{BI}, \mathrm{Bakr} \mathrm{AA}$. Intradermal injection of PPD as a novel approach of immunotherapy in anogenital warts in pregnant women. Dermatologic Therapy, 2011; 24: 137-43.

5. Rozmus-Warcholińska W, Loch T, Czuba B, Mazurek U, Mucha J. Genital warts associated with HPV infection during II and III trimester of pregnancy-a case report and analysis of treatment options. . 2007; 78(11): 888-91.

6. Centers for Disease Control and Prevention. Sexually transmitted diseases treatment guidelines. MMWR 2010; 59(No.RR-12): 70-3.

7. Nath D, Kumar B, Sharma KV, Kaur I, Gupta R, Malhotra S. Comparison of podophyllin and trichloroacetic acid for the treatment of genital warts. IJDVL , 1990; 56(1): 22-4.

8. Centers for Disease Control and Prevention. Sexually transmitted diseases treatment guidelines. MMWR 2006; 55(No.RR-11): 62-6.

9. Schwartz DB, Greenberg MD, Daoud Y, Reid R. Genital condylomas in pregnancy: use of trichloroacetic acid and laser therapy. Am J Obstet Gynecol, 1988; 158: 1407-16.

10. Matsunaga J, Bergman A, Bhatta NN. Genital condylomata acuminata in pregnancy: 
effectiveness, safety and pregnancy outcome following cryotherapy. British Journal of Obstetrics and Ciynaecology, 1987; 94: 168-72.

11. Lacey CJN, Woodhall SC, Wikstrom A, Ross J. IUSTI: 2010 European Guideline for the Management of Anogenital Warts in Adults, 2010: 1-18.

12. Tabari ST, Javadian M, Barat S. The efficacy of podophylin $20 \%$ and thricholoroacetic acid $30 \%$ in the treatment of genital wart. Casp J Intern Med, 2010; 1(1): 16-9.

13. Scheinfeld N, Lehman DS. An evidence-based review of medical and surgical treatments of genital warts. Dermatology Online Journal 2006; $12(3): 5$. 